\title{
Significance of hemogram on diagnosis of acute appendicitis during pregnancy
}

\author{
๑ Hamza Çınar, M.D., ${ }^{1} \odot$ Ali Aygün, M.D., ${ }^{2} \odot$ Murat Derebey, M.D., ${ }^{3} \odot$ İsmail Alper Tarım, M.D., ${ }^{4}$

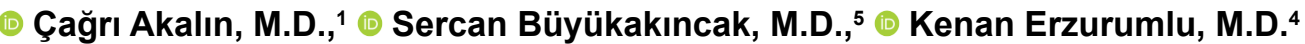

\author{
1Department of General Surgery, Ordu University Faculty of Medicine, Ordu-Turkey \\ ${ }^{2}$ Department of Emergency Medicine, Ordu University Faculty of Medicine, Ordu-Turkey \\ ${ }^{3}$ Department of General Surgery, Tatvan State Hospital, Bitlis-Turkey \\ ${ }^{4}$ Department of General Surgery, Ondokuz Mayıs University Faculty of Medicine, Samsun-Turkey \\ ${ }^{5}$ Department of General Surgery, Akçaabat Haçkalı Baba State Hospital, Trabzon-Turkey
}

\begin{abstract}
BACKGROUND: Acute appendicitis (AA) is the most common emergency surgical condition during pregnancy after obstetric and gynecological pathologies. Urgent and accurate diagnosis of AA in pregnant patients reduces maternal and fetal morbidity/mortality rates. This study evaluated the significance of hemogram to diagnose AA during pregnancy.
\end{abstract}

METHODS: Forty-seven pregnant patients operated for AA in the Ordu or Ondokuz Mayis University Medical School Hospitals between January 2007 and December 2017 were compared with 47 healthy pregnant women in terms of hemogram parameters, including the white blood cell (WBC) count, neutrophil count, lymphocyte count, platelet count, neutrophil-to-lymphocyte ratio (NLR), platelet-to-lymphocyte ratio (PLR), mean platelet volume (MPV), and red cell distribution width (RDW) values. The operated group was evaluated based on post-operative pathologic results and subclassified into appendicitis positive (Group A) and appendicitis negative (Group B) groups. The subgroups were compared to the control group.

RESULTS: The WBC and neutrophil count and mean NLR and PLR values were significantly higher in Group A compared to Group B and the control group $(p<0.00 \mathrm{I})$. The mean lymphocyte count was significantly lower in Group A compared to other groups $(p<0.00 \mathrm{I})$. The MPV and RDW values and mean platelet count showed no significant difference between groups $(p>0.05)$. When cutoff values for WBC, neutrophil count, NLR, PLR, and lymphocyte counts were set to $>10300,>7950,>5.50,>155.2$, and $\leq 1330$, respectively, the sensitivity rates were $72.5 \%, 80 \%, 90 \%, 77.5 \%$ and $85 \%$, whereas specificity rates were $72.3 \%, 79.7 \%, 89.4 \%, 74.5 \%$, and $82.5 \%$, respectively.

CONCLUSION: When comparing pregnant women diagnosed with AA to patients operated for suspected AA and healthy pregnant women, the WBC and neutrophil count and NLR and PLR values were found to be significantly higher, whereas lymphocyte counts were lower. In addition to medical history, physical examination and imaging techniques, hemogram parameters should be considered to diagnose $A A$ in pregnant women.

Keywords: Appendicitis; diagnosis; hemogram; lymphocyte; neutrophil; pregnancy.

\section{INTRODUCTION}

Acute appendicitis (AA) is the most common surgical pathology diagnosed in patients admitted to emergency departments with abdominal pain. ${ }^{\left[{ }^{I}\right]} \mathrm{AA}$ is among the most common indications for emergency surgery during pregnancy after obstetric and gynecological pathologies. The incidence of AA is I in 500-2000 pregnant women. ${ }^{[2,3]}$ AA occurs mostly during the second trimester, although it can be seen at any time during pregnancy. ${ }^{[4]}$ The urgent and accurate diagnosis

Cite this article as: Çınar H, Aygün A, Derebey M, Tarım İA, Akalın Ç, Büyükakıncak S, et al. Significance of hemogram on diagnosis of acute appendicitis during pregnancy. Ulus Travma Acil Cerrahi Derg 2018;24:423-428.

Address for correspondence: Hamza Çınar, M.D.

Ordu Üniversitesi Tıp Fakültesi, Genel Cerrahi Anabilim Dalı, Altınordu, 52100 Ordu, Turkey

Tel: +90 452 - 22652 I4 E-mail: drhamzacinar@gmail.com

Ulus Travma Acil Cerrahi Derg 2018;24(5):423-428 DOI: 10.5505/tjtes.20I8.62753 Submitted: 20.05.2018 Accepted: 14.08.2018 Online: 28.09.2018

Copyright 2018 Turkish Association of Trauma and Emergency Surgery 
of $A A$ is essential for preventing potential complications for the mother and/or fetus. Symptoms including nausea, vomiting, and anorexia are usually seen in the early period of pregnancy and also in $\mathrm{AA}$; therefore, the diagnosis of this condition is challenging for clinicians. Physiological increases in the leucocyte count and C-reactive protein (CRP) levels may be observed during pregnancy. Tomography is avoided in pregnant women to protect the fetus from ionized radiation. The preferred imaging techniques are ultrasonography and/ or magnetic resonance imaging. ${ }^{[5,6]}$ Considering these factors, diagnosing AA during pregnancy can be challenging for physicians, and therefore, the diagnosis can be delayed.

Hemogram parameters including the white blood cell (WBC) count, neutrophil count, lymphocyte count, neutrophil-tolymphocyte ratio (NLR), platelet-to-lymphocyte ratio (PLR), and mean platelet volume (MPV) are inflammatory markers. The changing levels of these parameters are measured in several inflammatory pathologies. ${ }^{[7]}$

It is extremely important to diagnose suspected AA early in pregnant women and to avoid unnecessary surgery. The aim of this study is to determine the hemogram parameters, which are readily available and are evaluated in emergency conditions as a diagnostic tool in diagnosis of AA during pregnancy.

\section{MATERIALS AND METHODS}

The study included 47 pregnant patients who were operated for suspected AA and 47 healthy pregnant women between January 2007 and December 2017 at Medical School Hospitals of the Ordu or Ondokuz Mayis University. The hemogram parameters including the WBC, neutrophil count, lymphocyte count, platelet count, NLR, PLR, MPV, and red cell distribution width (RDW) values were retrospectively examined from the medical records of the patients. The post-operative pathological results of appendix specimens were also investigated. All patients with a final pathological evaluation reported as acute focal appendicitis, acute suppurated appendicitis, acute perforated appendicitis, and acute gangrenous appendicitis were included in the AA group (Group A), whereas patients with a normal histopathology were included in the non-appendicitis group (Group B). Forty-seven healthy pregnant women who were under routine pregnancy followup during the same period at the obstetrics clinics of the same hospitals were included as the control group. Exclusion criteria were the presence of hematological diseases, chronic renal failure, chronic liver disease, chronic obstructive lung disease, asthma, autoimmune diseases, cancer, rheumatoid arthritis, bacterial, viral or parasitic infection, immune deficiency, alcohol or tobacco use, and missing records. The age, gestational age, time to diagnosis, length of hospitalization, type of surgical incision, WBC, neutrophil, lymphocyte, and platelet count, and the NLR, PLR, MPV, and RDW values for each patient were recorded. The study was approved by the Ethics Committee of the Ordu University.
All tests were performed on blood samples obtained via venous system and collected into ethylene diamine tetra acetic acid tubes. Hemograms that were taken within 24 hours prior to surgery were accepted for the AA group. The WBC, neutrophil, platelet, and lymphocyte counts, and the MPV and RDW values were analyzed via hemogram samples. The NLR and PLR values were calculated by dividing neutrophil and platelet counts to lymphocyte count. Hematological parameters were measured by an automated hematology analyzer (Abbott Cell-Dyn 3700 Hematology Analyzer, Abbott Diagnostics, USA). The upper limits of the reference intervals were as follows: leukocyte counts (WBC); 4600-10200

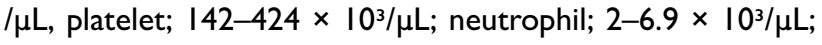

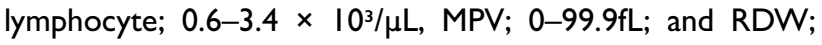
$0 \%-16.2 \%$.

\section{Statistical Analysis}

Statistical analysis was performed using the SPSS 22.0 software (IBM Corporation, Armonk, NY, USA). The ShapiroWilk test was used to determine the compliance of data to a normal distribution, and the Levene test was used to determine the homogeneity of variances among the groups. The independent samples $\mathrm{T}$ test with bootstrap results was used to compare two independent groups, whereas the Mann-Whitney $U$ test was used with the Monte Carlo simulation technique. One-way analysis of variance (robust test: Browne-Forsythe) was used together with bootstrap results to compare more than two groups with other groups. The Kruskal-Wallis $\mathrm{H}$ test, least significant differences, and Games-Howell tests were used for post-hoc analysis. The correlation between classification of the patient groups separated by cutoff values was calculated according to the variables, and real classification was expressed by examination of sensitivity and specificity using the receiver operating characteristic (ROC) curve analysis. Quantitative data are expressed as the mean \pm standard deviation, median-interquartile range, or median and range (maximum-minimum). Categorical data are expressed as $\mathrm{n}$ (number) or percentage (\%) and analyzed by Fisher's exact test.

\section{RESULTS}

All the patients who underwent surgery were divided into two groups based on their pathology results; Group A consisted of 40 patients (85.1\%) with AA and Group B with 7 ( $14.9 \%)$ patients without appendicitis. There was no significant difference between groups in terms of age, time period of admission to diagnosis, or the length of post-operative hospitalization ( $p>0.05$ ). Of 40 patients in Group A, 16 (40\%), 20 $(50 \%)$, and $4(10 \%)$ were in the $1^{\text {st }}, 2^{\text {nd }}$, and $3^{\text {rd }}$ trimester of pregnancy, respectively, whereas in Group B, 4 (57.1\%) and 3 (42.9\%) were in the $I^{\text {st }}$ and $2^{\text {nd }}$ trimester of pregnancy, respectively. The control group consisted of 15 (31.9\%), 17 (36.1\%), and $15(31.9 \%)$ subjects in the $1^{\text {st }}, 2^{\text {nd }}$, and $3^{\text {rd }}$ trimester of pregnancy, respectively. No significant difference was found 
between Group A and Group B for gestational age ( $>0.05)$. Laparotomy was performed in all patients using McBurney's or right paramedian incisions. In pregnant women diagnosed with AA, McBurney's incision was mostly preferred (78.7\%). Paramedian incision was preferred in patients with older gestational age. The mean post-operative length of hospitalization was 4.18 $\$ 3.09$ days in Group $A$ and $3.57 \pm 1.39$ days in Group B, and no significant difference was found between the groups in terms of length of hospitalization ( $p>0.05)$. A significantly higher WBC and neutrophil counts and the mean NLR and PLR values were detected in Group A compared to
Group B and the control group $(p<0.001)$. The mean lymphocyte count was significantly lower in Group A compared to other groups $(p<0.00 I)$. There was no significant difference between groups in terms of the mean MPV and RDW values and platelet count $(\mathrm{p}>0.05)$ (Table I).

The ROC curve analysis was performed to evaluate the predictive ability of hemogram parameters to diagnose AA in pregnant women. Sensitivity, specificity, and accuracy rate values for hemogram parameters were estimated based on cutoff values determined by ROC analyses (Table 2).

Table I. Comparison of groups for age, gestational age, time to diagnosis with symptoms, surgical incision, and hemogram parameters

\begin{tabular}{|c|c|c|c|c|}
\hline & Group A $(n=40)$ & Group B $(n=7)$ & Control Group $(n=47)$ & $\mathbf{p}$ \\
\hline Age & $27.0 \pm 5.55$ & $25.14 \pm 5.08$ & $29.74 \pm 6.13$ & 0.36 \\
\hline Gestational age (weeks) & $16.88 \pm 7.72$ & $13.0 \pm 4.89$ & $21.60 \pm 9.77$ & 0.009 \\
\hline Time to diagnosis with symptoms (hours) & $23.28 \pm 21.20$ & $12.0 \pm 7.97$ & - & 0.175 \\
\hline \multicolumn{5}{|l|}{ Surgical incision type } \\
\hline Paramedian & $20 \%(n=8)$ & $28.57 \%(n=2)$ & - & 0.630 \\
\hline McBurney & $80 \%(n=32)$ & $71.42(n=5)$ & - & \\
\hline Post-operative hospital stay (days) & $4.18 \pm 3.09$ & $3.57 \pm 1.39$ & - & 0.617 \\
\hline White blood cells $(\mathrm{K} / \mu \mathrm{L})^{*}$ & $12886 \pm 4785^{a}$ & $13194 \pm 3520^{a}$ & $9063 \pm 1869^{b}$ & $<0.001$ \\
\hline Mean platelet volume* (fL) & $8.03 \pm 1.22$ & $7.56 \pm 1.27$ & $7.51 \pm 0.90$ & 0.07 \\
\hline Red cell distribution width* (\%) & $14.83 \pm 2.18$ & $14.78 \pm 1.26$ & $14.23 \pm 1.26$ & 0.255 \\
\hline Neutrophil count $(\mathrm{K} / \mu \mathrm{L})^{*}$ & $11198 \pm 4624^{a}$ & $10967 \pm 3550^{\mathrm{a}}$ & $6561 \pm 1616^{b}$ & $<0.001$ \\
\hline Lymphocyte count $(\mathrm{K} / \mu \mathrm{L})^{*}$ & $1093 \pm 442^{c}$ & $|4| 5 \pm 4 \mid 3^{b}$ & $|845 \pm 64|^{a}$ & $<0.001$ \\
\hline Neutrophil-to-lymphocyte ratio** & $12.10(2.28-37.10)^{\mathrm{a}}$ & $7.70(3.40-13.60)^{b}$ & $3.57(1.22-28.90)^{c}$ & $<0.001$ \\
\hline Platelet-to-lymphocyte ratio** & $218.91(93.10-735.13)^{\mathrm{a}}$ & $190.80(93.10-289.60)^{\mathrm{a}, \mathrm{b}}$ & $130.30(58.65-429.03)^{\mathrm{b}}$ & $<0.001$ \\
\hline Platelet count $(\mathrm{K} / \mu \mathrm{L})^{*}$ & $229125 \pm 74976$ & $261000 \pm 74446$ & $238276 \pm 67 \mid 48$ & 0.528 \\
\hline
\end{tabular}

a,b,cIndicate inter-group differences within the row

Mann-Whitney $U$ test (Monte Carlo)-one-way analysis of variance (Browne-Forsythe)-(Bootstrap)

Post-hoc test: least significant difference-Games-Howell

Kruskal-Wallis test

Post-hoc test (Monte Carlo): nonparametric post-hoc test (Miller, 1966)

"Mean \pm standard deviation; "** Median; (range, maximum-minimum).

Table 2. Sensitivity and specificity rates for hemogram parameters based on cut-off values in pregnant women diagnosed with AA

\begin{tabular}{lccccc}
\hline & $\begin{array}{c}\text { Hemogram parameters } \\
\text { (cut-off values) }\end{array}$ & $\begin{array}{c}\text { Sensitivity } \\
\text { (\%) }\end{array}$ & $\begin{array}{c}\text { Specificity } \\
\text { (\%) }\end{array}$ & $\begin{array}{c}\text { Accuracy rate } \\
\text { (\%) }\end{array}$ & $\begin{array}{c}\text { AUC } \pm S E \\
\text { White blood cells }(\mathrm{K} / \mathrm{mL})\end{array}$ \\
Mean platelet volume & $>10300$ & 72.5 & 72.3 & 72.4 & $0.815 \pm 0.046$ \\
Red cell distribution width & $>7.65$ & 62.5 & 60.6 & 60.9 & $0.648 \pm 0.063$ \\
Neutrophil count $(\mathrm{K} / \mathrm{mL})$ & $>14.2$ & 57.5 & 53.2 & 55.1 & $0.552 \pm 0.063$ \\
Lymphocyte count $(\mathrm{K} / \mathrm{mL})$ & $>7950$ & 80.0 & 79.7 & 81.6 & $0.880 \pm 0.038$ \\
Platelet count $(\mathrm{K} / \mathrm{mL})$ & $<1330$ & 85 & 82.5 & 85.0 & $0.864 \pm 0.042$ \\
Neutrophil-to-lymphocyte ratio & $>225000$ & 57.4 & 47.5 & 50.5 & $0.536 \pm 0.063$ \\
Platelet-to-lymphocyte ratio & $>5.50$ & 90.0 & 89.4 & 90.8 & $0.920 \pm 0.034$ \\
\hline
\end{tabular}

ROC curve analysis (Youden index J-Honley and McNell). AA: Acute appendicitis; AUC: Area under the receiver operating characteristic curve, SE: Standard error. 
To predict AA, the sensitivity and specificity values for various hemogram parameters at set cutoff values were as follows: for WBC; $72.5 \%$ sensitivity and $72.3 \%$ specificity at cutoff > 10300 cells $/ \mathrm{mL}$, for neutrophil count; $80 \%$ sensitivity and $79.7 \%$ specificity at cutoff $>7950$ cells/ $\mathrm{mL}$, for lymphocyte count; $<1330$ cells $/ \mathrm{mL}$ had $85 \%$ sensitivity and $82.5 \%$ specificity, for NLR; $90 \%$ sensitivity and $89.4 \%$ specificity at cutoff $>5.50$, for PLR; $77.5 \%$ sensitivity and $74.5 \%$ specificity at cutoff $>155.2$, for platelet count; $57.4 \%$ sensitivity and $47.5 \%$ specificity at cutoff $>225000$ cells $/ \mathrm{mL}$; for RDW, $57.5 \%$ sensitivity and $53.2 \%$ specificity at cutoff >14.2; and for MPV; $62.5 \%$ sensitivity and $60.6 \%$ specificity at cutoff $>7.65$.

\section{DISCUSSION}

Diagnosis of AA in pregnant patients is more difficult compared to non-pregnant patients due to anatomical and physiological changes in pregnancy. Physiological features of pregnancy such as anorexia, nausea, and vomiting can mask AA symptoms. Uterus enlargement and reduced tonus of abdominal muscles causes uterus growing into the abdomen and the appendix displacement as well. ${ }^{[8]}$ The utilization of radiological imaging techniques is limited in pregnant patients for the goal of fetus protection. Therefore, it is difficult to diagnose AA by history and physical examination. Delay in diagnosis increases the risk of appendix perforation. Perforation leads to peritonitis and sepsis, which causes increased mortality and morbidity rates for the mother and baby. ${ }^{\left[{ }^{[-10]}\right.}$ Babaknia et al. $^{\left[{ }^{\prime I}\right]}$ have reported that the rate of fetal loss was $1.5 \%$ in non-perforated and $35.7 \%$ in perforated AA patients. The incidence of perforated appendicitis during pregnancy depends on the time between the onset of symptoms and surgical intervention, and the risk for perforation is increased by over

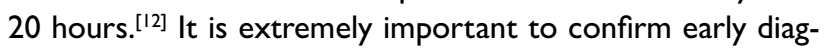
nosis in pregnant patients with suspected AA. Although diagnosis should be confirmed urgently, negative appendectomy should be avoided as well. Negative appendectomy rates during pregnancy have been reported to range between $3 \%$ and $23 \% .^{[13,14]}$ The rate of negative appendectomy was $14.9 \%$ in our study.

Hemogram is a readily available and valuable test, and it plays an essential role in diagnosis of AA. Among the hemogram parameters, the WBC, neutrophil, and lymphocyte counts and NLR, PLR, and MPV act as inflammatory markers. The predictive value of these markers for $A A$ is currently becoming more promising. ${ }^{[5,15,16]}$ Leucocytosis is commonly observed in patients with $A A$. In our study, the WBC count of pregnant AA patients was found to be $12886 \pm 4785 \mathrm{~mm}^{3}$, and there was a significant difference compared to healthy pregnant women $(p<0.00 I)$. Estimated sensitivity and specificity values for WBC with a cutoff value $>10300$ were $72.5 \%$ and $72.3 \%$, respectively. Despite the mentioned sensitivity and specificity rates, the WBC count can increase up to $18.000-30.000 \mathrm{~mm}^{3}$ at a period closer to delivery. ${ }^{[8]}$ Therefore, the WBC count alone may be used as a specific predictor of AA during preg- nancy. WBC should be used in combination with parameters such as the neutrophil and lymphocyte counts and NLR and PLR with higher sensitivity and specificity values. ${ }^{[5]}$

In several inflammatory diseases, regular response of circulating leukocytes is an increased level of neutrophil and reduced level of lymphocyte counts. ${ }^{[17]} \mathrm{AA}$ is an inflammatory disease; therefore, a high neutrophil count and low lymphocyte count should be expected. Thus, in our study, the mean neutrophil count was higher and mean lymphocyte count was lower in the appendicitis group compared to other groups $(p<0.00 \mathrm{I})$. Based on cutoff values, neutrophil and lymphocyte counts showed $80 \%$ and $85 \%$ sensitivity and $79.7 \%$ and $82.5 \%$ specificity, respectively. In the study by Yazar et al., ${ }^{[5]}$ high neutrophil and low lymphocyte values were found in pregnant patients with appendicitis. Recently, several studies suggested that an increased NLR or PLR could be better predictors of AA compared to CRP, WBC, or the neutrophil count alone. ${ }^{[5,18,19]}$ A recent study by Yazar et al. ${ }^{[5]}$ including 28 pregnant women with AA found $78.6 \%$ and $100 \%$ sensitivity and $80 \%$ and $42.9 \%$ specificity, based on cutoff values for NLR and PLR, respectively. Additionally, they have reported accurate diagnosis of AA with a $90.5 \%$ rate when NLR and PLR were combined with the WBC count, CRP level, and lymphocyte count. Similarly to previous studies, our study showed that NLR and PLR, based on cutoff values, have $90 \%$ and $77.5 \%$ sensitivity and $89.4 \%$ and $74.5 \%$ specificity, respectively. Among the hemogram parameters, a higher sensitivity and specificity were observed for NLR in terms of AA diagnosis in pregnant women.

MPV is the most common marker for the production and functional status of platelet, and it reflects inflammatory burden. There are several studies that indicate that MPV values are useful in diagnosing AA. Narci et al. ${ }^{[20]}$ have suggested that high MPV values can be used for the diagnosis of AA. In another study, Albayrak et al. ${ }^{[2]}$ found a significantly lower MPV level in patients with AA compared to the control group. Similarly, no difference was found between the groups in a study by Yazıcı et al., ${ }^{[5]}$ which compared platelet counts in pregnant women. However, in our study, there was no significant difference in MPV values between pregnant women diagnosed with AA and the control group ( $p>0.05)$. The predictive value of RDW has been evaluated in several studies among patients with appendicitis; however these studies have concluded with controversial results. ${ }^{[22-24]}$ To the best of our knowledge, ours is the first study to evaluate a predictive value of RDW levels to diagnose AA during pregnancy. We could not demonstrate a significant predictive value of RDW in our study.

\section{Conclusion}

In pregnant patients with suspected AA, a more urgent and accurate diagnosis can be achieved using the WBC, neutrophil, and lymphocyte counts and NLR and PLR values in combination with medical history, physical examination, and 
imaging techniques. As a result, maternal and fetal morbidity/ mortality rates can be reduced and negative laparotomy rates can be minimized. Our results can contribute to the limited literature available on AA in pregnant women.

\section{Limitation of the study: Retrospective design based on analy-} ses of patient records and a relatively small sample size.

\section{Conflict of interest: None declared.}

\section{REFERENCES}

1. Demircan A, Aygencel G, Karamercan M, Ergin M, Yilmaz TU, Karamercan A. Ultrasonographic findings and evaluation of white blood cell counts in patients undergoing laparotomy with the diagnosis of acute appendicitis [Article in Turkish]. Ulus Travma Acil Cerrahi Derg 2010;16:248-52.

2. Andersen B, Nielsen TF. Appendicitis in pregnancy: diagnosis, management and complications. Acta Obstet Gynecol Scand 1999;78:758-62.

3. Arer İM, Alemdaroğlu $S$, Yeşilağaç H, Yabanoğlu $H$. Acute appendicitis during pregnancy: case series of 20 pregnant women. Ulus Travma Acil Cerrahi Derg 2016;22:545-8. [CrossRef]

4. Onder A, Kapan M, Arikanoglu Z, Sak ME, Gumus M, Taskesen F, et al. Acute Appendicits in Pregnancy: Evaluation of 129 Patients During 20 years. J Curr Surg 2012;2:4-10.

5. Yazar FM, Bakacak M, Emre A, Urfalıoglu A, Serin S, Cengiz E, et al. Predictive role of neutrophil-to-lymphocyte and platelet-to-lymphocyte ratios for diagnosis of acute appendicitis during pregnancy. Kaohsiung J Med Sci 2015;31:591-6. [CrossRef]

6. Franca Neto AH, Amorim MM, Nóbrega BM. Acute appendicitis in pregnancy: literature review. Rev Assoc Med Bras (1992) 2015;61:1707. [CrossRef]

7. Acar E, Özcan Ö, Deliktaş H, Beydilli H, Kırlı İ, Alatas ÖD, et al. Laboratory markers has many valuable parameters in the discrimination between acute appendicitis and renal colic. Ulus Travma Acil Cerrahi Derg 2016;22:17-22.

8. Jung SJ, Lee DK, Kim JH, Kong PS, Kim KH, Bae SW. Appendicitis during Pregnancy: The Clinical Experience of a Secondary Hospital. J Korean Soc Coloproctol 2012;28:152-9. [CrossRef]

9. Bickell NA, Aufses AH Jr, Rojas M, Bodian C. How time affects the risk of rupture in appendicitis. J Am Coll Surg 2006;202:401-6. [CrossRef]

10. Al-Qudah MS, Amr M, Sroujieh A, Issa A. Appendectomy in pregnancy: the experience of a university hospital. J Obstet Gynaecol 1999;19:3624. [CrossRef]

11. Babaknia A, Parsa H, Woodruff JD. Appendicitis during pregnancy. Obstet Gynecol 1977;50:40-4.

12. Yilmaz HG, Akgun Y, Bac B, Celik Y. Acute appendicitis in pregnancyrisk factors associated with principal outcomes: a case control study. Int J Surg 2007;5:192-7. [CrossRef]

13. McGee TM. Acute appendicitis in pregnancy. Aust N Z J Obstet Gynaecol 1989;29:378-85. [CrossRef]

14. McGory ML, Zingmond DS, Tillou A, Hiatt JR, Ko CY, Cryer HM. Negative appendectomy in pregnant women is associated with a substantial risk of fetal loss. J Am Coll Surg 2007;205:534-40. [CrossRef]

15. Peng W, Li C, Wen TF, Yan LN, Li B, Wang WT, et al. Neutrophil to lymphocyte ratio changes predict small hepatocellular carcinoma survival. J Surg Res 2014;192:402-8. [CrossRef]

16. Bhat T, Teli S, Rijal J, Bhat H, Raza M, Khoueiry G, et al. Neutrophil to lymphocyte ratio and cardiovascular diseases: a review. Expert Rev Cardiovasc Ther 2013;11:55-9. [CrossRef]

17. Zahorec R. Ratio of neutrophil to lymphocyte counts--rapid and simple parameter of systemic inflammation and stress in critically ill. Bratisl Lek Listy 2001;102:5-14.

18. Markar SR, Karthikesalingam A, Falzon A, Kan Y. The diagnostic value of neutrophil: lymphocyte ratio in adults with suspected acute appendicitis. Acta Chir Belg 2010;110:543-7. [CrossRef]

19. Goodman DA, Goodman CB, Monk JS. Use of the neutrophil:lymphocyte ratio in the diagnosis of appendicitis. Am Surg 1995;61:257-9.

20. Narci H, Turk E, Karagulle E, Togan T, Karabulut K. The Role of Mean Platelet Volume in the Diagnosis of Acute Appendicitis: A Retrospective Case-Controlled Study. Iran Red Crescent Med J 2013;15:e11934.

21. Albayrak Y, Albayrak A, Albayrak F, Yildirim R, Aylu B, Uyanik A, et al. Mean Platelet Volume: A New Predictor in Confirming Acute Appendicitis Diagnosis. Clin Appl Thromb Hemost 2011;17:362-6. [CrossRef]

22. Narci H, Turk E, Karagulle E, Togan T, Karabulut K. The role of red cell distribution width in the diagnosis of acute appendicitis: a retrospective case-controlled study. World J Emerg Surg 2013;8:46. [CrossRef]

23. Tanrikulu CS, Tanrikulu Y, Sabuncuoglu MZ, Karamercan. MA, Akkapulu N, Coskun F. Mean platelet volume and red cell distribution width as a diagnostic marker in acute appendicitis. Iran Red Crescent Med J 2014;16:e10211. [CrossRef]

24. Ertekin B, Hasan K, Erdemir E, Doğan E, Acar T, Demir LS. Efficacy of Use of Red Cell Distribution Width as a Diagnostic Marker in Acute Appendicitis. Eurasian J Emerg Med 2017;16:29-33. [CrossRef] 


\title{
ORİJINAL ÇALIŞMA - ÖZET
}

\section{Gebelikte hemogramın akut apandisit tanısındaki önemi}

Dr. Hamza Çınar, ${ }^{1}$ Dr. Ali Aygun, ${ }^{2}$ Dr. Murat Derebey, ${ }^{3}$ Dr. İsmail Alper Tarım, ${ }^{4}$ Dr. Çağrı Akalın, ${ }^{1}$ Dr. Sercan Büyükakıncak, ${ }^{5}$ Dr. Kenan Erzurumlu ${ }^{4}$

\author{
${ }^{1}$ Ordu Üniversitesi Tıp Fakültesi, Genel Cerrahi Anabilim Dalı, Ordu \\ ${ }^{2}$ Ordu Üniversitesi Tıp Fakültesi, Acil Tıp Anabilim Dalı, Ordu \\ ${ }^{3}$ Tatvan Devlet Hastanesi, Genel Cerrahi Kliniği, Bitlis \\ ${ }^{4}$ Ondokuz Mayıs Üniversitesi Tıp Fakültesi, Genel Cerrahi Anabilim Dalı, Samsun \\ ${ }^{5}$ Akçaabat Haçkalı Baba Devlet Hastanesi, Genel Cerrahi Kliniği, Trabzon
}

AMAÇ: Akut apandisit (AA) gebelik döneminde obstetrik ve jinekolojik patolojilerden sonra en sık acil cerrahi gerektiren durumdur. Gebe hastalarda AA tanısının hızlı ve doğru konulması maternal ve fetal morbite/mortalite oranlarını azaltır. Bu çalışma, hemogramın gebelik döneminde AA tanısı koymadaki önemini irdelemektedir.

GEREÇ VE YÖNTEM: Ordu veya Ondokuz Mayıs Üniversitesi Tıp Fakültesi Hastanesi'nde Ocak 2007-Aralık 2017 yılları arasında AA nedeniyle ameliyat edilen 47 gebe hasta ile 47 sağlıkı gebe hastanın hemogram parametrelerinden beyaz kan hücresi (WBC) sayısı, nötrofil sayısı, lenfosit sayısı, platelet sayısı, nötrofil/lenfosit oranı (NLO), platelet/lenfosit oranı (PLO), mean platelet volüm (MPV) ve kırmızı hücre dağıım genişliği (RDW) değerleri kıyaslandı. Ameliyat edilen hastalar, patoloji sonucu apandisit olanlar Grup A normal olanlar ise Grup B olarak ikiye ayrıldı ve kontrol grubu ile kıyaslandı.

BULGULAR: Grup A hastalarının WBC sayısı, nötrofil sayısı, ortalama NLO ve PLO değerleri Grup B ve kontrol hastalarından anlamlı olarak yüksek tespit edildi $(p<0.001)$. Lenfosit sayısı ortalamasının Grup A hastalarında diğer gruplardan anlamlı olarak düşük olduğu görüldü $(p<0.00 I)$. MPV, RDW ve ortalama platelet sayısı açısından gruplar arasında anlamlı bir farklılık yoktu ( $p>0.05)$. WBC sayısı, nötrofil sayısı, NLO, PLO ve lenfosit sayısı için kestirim değerleri sırasıyla $>10300,>7950,>5.50,>155.2$ ve $\leq 1330$ olarak alındığında sensivite oranları sırasıyla \%72.5, \%80, \%90, \%77.5 ve $\% 85$ olarak gözlenirken spesifite oranları ise sırasıyla \%72.3, \%79.7, \%89.4, \%74.5 ve \%82.5 olarak tespit edildi.

TARTIŞMA: Akut apandisit tanısı olan gebe kadınlarda WBC sayısı, nötrofil sayısı, NLO ve PLO değerleri kontrol grubu ve apandisit şüphesi nedeniyle ameliyat edilen hastalardan istatistiksel olarak anlamlı olacak şekilde yüksek bulunurken lenfosit sayısı ise düşük bulunmuştur. Gebe kadınlarda AA tanısı koymak için anamnez, fizik muayene ve görüntüleme yöntemleri ile birlikte hemogram parametreleride göz önünde bulundurulmalıdır. Anahtar sözcükler: Apandisit; gebelik; hemogram; lenfosit; nötrofil; teşhis.

Ulus Travma Acil Cerrahi Derg 2018;24(5):423-428 doi: 10.5505/tjtes.2018.62753 